\title{
Dokumenty życia społecznego w bibliotekach akademickich - niektóre dylematy
}

$D^{\prime}$ okumenty życia społecznego (dalej: dżs) w postaci odrębnego zbioru pojawiły się w bibliotekach akademickich stosunkowo niedawno. W znaczących bibliotekach pierwsze samodzielne, wyodrębnione ze zbiorów głównych, działy tworzono w latach 60 . W innego typu bibliotekach powstały później. W innych, mniejszych, przede wszystkim publicznych, szczególną uwagę na ten typ materiałów, najczęściej utożsamianych z drukami o charakterze regionalnym, zwrócono dopiero w ostatnich latach. W Bibliotece Uniwersyteckiej w Warszawie (dalej: BUW) formalnie Oddział Dokumentów Życia Społecznego powołano z dniem 1 października 1985 r. Jako jeden ze zbiorów specjalnych, pod nazwą Gabinetu Dokumentów Życia Społecznego (dalej: GDŻS), zajmuje on trwałą pozycję w strukturze Biblioteki. Być może nadszedł więc moment na kilka uwag, związanych z istnieniem tego typu oddziałów, ich doświadczeniami i problemami. Najłatwiej jest mówić o tym na podstawie zbiorów własnej biblioteki, ale obserwacje poczynione przy okazji odwiedzin innych placówek w jakimś sensie upoważniają do pewnych uogólnień. Tym bardziej, że aktualna produkcja wydawnicza powoduje istny zalew wszelkiego rodzaju reklamami, informacjami, propozycjami udziału w imprezach itp. Dzisiejszy człowiek żyje więc w świecie drobnych druków, które spotyka wszędzie. Druki te stały się nieodłącznym elementem współczesnego życia społecznego. Sytuacja ta znajduje swoje odbicie w bibliotekach, które zajmują się gromadzeniem tego typu dokumentów. W tym miejscu należy zaznaczyć, że w większości bibliotek druki nazywane dzisiaj doku- 
mentami życia społecznego były gromadzone od momentu ich powstania i do dziś stanowią ważną część zbiorów głównych. Korzystanie z nich jest utrudnione, najczęściej z powodu nieumiejętności ich wyszukiwania. Były one bowiem opracowywane zgodnie z obowiązującymi w danym okresie regułami, których przeciętny, współczesny użytkownik po prostu nie zna. Wydaje się, że szeroko zakrojona retrokonwersja zbiorów uwidoczni ten typ druków i uczyni je bardziej dostępnymi.

Dzisiaj docenia się znaczącą rolę dżs-ów w badaniach naukowych, ich funkcję dokumentacyjną i informującą o różnych aspektach życia społecznego w danym okresie historycznym. Pomimo ich ogromnego znaczenia dla nauki i prawie półwiecznej tradycji istnienia tych specyficznych działów w historii bibliotek, nadal odczuwa się niedosyt uniwersalnych rozwiązań w zakresie ich zorganizowania. Poszczególne biblioteki wciąż pojedynczo borykają się z wieloma problemami. Środowiska bibliotekarskie kilkakrotnie podejmowały próby wypracowania pewnych rozwiązań m.in. poprzez organizowanie konferencji i seminariów poświęconych tej problematyce, a także poprzez nieliczne publikacje. Mimo usilnych starań nie wypracowano do tej pory formuły jednoznacznie definiującej dżs-y. Część bibliotek, przede wszystkim akademickich, przyjęła definicję stworzoną przez Bibliotekę Narodową, która dokumentami życia społecznego określa druki dotyczące poszczególnych dziedzin życia współczesnego, odzwierciedlające wewnętrzną działalność różnego rodzaju organizacji, stowarzyszeń i instytucji, które są wydawane w celu osiągnięcia doraźnych celów informacyjnych, propagandowych, reklamowych i normatywnych, przeznaczone dla określonego kręgu odbiorców i najczęściej do pozaksięgarskiego sposobu rozprowadzania, charakteryzujące się różnorodną formą i szatą graficzną, występujące w postaci druków ulotnych, zwartych i ciągłych ${ }^{1}$. Jest to jednak definicja bardzo ogólna, obejmująca swoim zasięgiem prawie każdy typ wydawnictw i zamiast dokładnie precyzować, wprowadza możliwość różnych interpretacji. Stąd w jednej bibliotece dany obiekt zaliczono do zbiorów głównych, w innej do dżs-ów, a w jeszcze innej do któregoś z innych zbiorów specjalnych. Brak precyzyjnej definicji implikuje dalsze trudności, które każda z bibliotek próbuje rozwiązać w pojedynkę. Niewątpliwie duże znaczenie ma tutaj tradycja danej placówki w zakresie organizacji zbiorów oraz różnego rodzaju przyzwyczajenia, a także brak współczesnej, wręcz o znaczeniu podsta-

${ }^{1}$ Zob. szerzej Z. Głowicka, Dokumenty życia społecznego w zbiorach Biblioteki Narodowej, „Biuletyn Informacyjny Biblioteki Narodowej” 2001, nr 1, s. 3-6. 
wowym, literatury poradnikowej w tym zakresie. Nadal z dziedziny bibliotekarstwa naukowego najbardziej przydatne wydają się prace naukowe sprzed kilkudziesięciu lat ${ }^{2}$. Jak już wspomniano, w ostatnich latach zorganizowano wprawdzie kilka konferencji poświęconych tej problematyce, ale nie rozwiązało to wielu problemów, z którymi borykają się biblioteki różnych szczebli³ . Nie do końca potrafią rozwiązać te problemy także biblioteki akademickie. Dotyczy to zarówno gromadzenia, opracowania, jak i przechowywania oraz udostępniania.

Zwykle biblioteki starają się stworzyć własne zasady gromadzenia, które stanowią podstawę wypracowanego i logicznego uzupełniania zbiorów, powiększania wyodrębnionych kolekcji. W przypadku dżs-ów jest to niezwykle trudne z wielu powodów. Zdarza się więc, że na początku uprawia się tzw. zbieractwo, bez logicznej koncepcji gromadzenia, odkładając opracowanie zasad na czas późniejszy. Należy przyznać, że do dzisiaj nie wiemy, jak precyzyjnie opracować zasady gromadzenia dla tej grupy zbiorów. Najczęściej stosowane są dwa sposoby opracowania. Jednym z nich jest tworzenie list gromadzonych materiałów, poprzez dokładne wyliczenie wszystkich form druków; najczęściej z uwzględnieniem kryterium formalno-treściowego. Po ich wyszczególnieniu dyrekcja biblioteki zarządzeniem wprowadza te zasady w życie. Listy zawierają kilkaset różnych form. Jest to dosyć częste rozwiązanie, ale zawierające pewne pułapki. Nigdy nie potrafimy przewidzieć, jakie nowe formy wydawnicze mogą pojawić się na rynku. W sytuacji, gdy się pojawią, powstaje konieczność dopisania tej nowej formy na listę gromadzonych druków, co wymusza podjęcie kolejnej formalnej decyzji o wprowadzeniu nowej formy wydawniczej do zasad gromadzenia. Aktualnie publikowana ogromna liczba i różnorodność druków musiałaby spowodować częste podejmowanie decyzji „nowelizujących” dotychczasowe zasady gromadzenia. Niektóre biblioteki, m.in. BUW, opracowując zasady gromadzenia dżs-ów, przy-

${ }^{2}$ Zob. Bibliotekarstwo naukowe z uwzględnieniem dokumentacji naukowo-technicznej, pod red. A. Łysakowskiego, Warszawa 1956.

${ }_{3}$ Zob. publikacje będące rezultatem konferencji poświęconych problematyce dokumentów życia społecznego: Dokumenty życia społecznego w bibliotece. Materiały z ogólnopolskiej konferencji zorganizowanej przez Bibliotekę Zakładu Ossolińskich we Wrocławiu w dniach 2-3 czerwca 1969 roku, pod red. J. Albina, Wrocław 1970; Dokumenty życia społecznego w bibliotece. Materiały konferencyjne, Osola 2001 r., Wrocław 2001; Druki ulotne i okolicznościowe. Wartości i funkcje. Materiały międzynarodowej konferencji naukowej, Wojnowice, 8-10 października 2004, pod red. K. Migonia, M. Skalskiej-Zlat, A. Żbikowskiej-Migoń przy współpr. E. Herden, Wrocław 2006. 
jęły inną metodę. Za punkt wyjścia wzięto charakterystykę księgozbioru głównego oraz zadań, jakie biblioteka powinna realizować. Zgodnie z tym założeniem zbiory dżs powinny być niejako przedłużeniem zbiorów głównych. W zasadach gromadzenia określa się zatem: zakres terytorialny gromadzenia, zakres tematyczny, zakres chronologiczny, następnie źródła wpływu, liczbę egzemplarzy oraz typy formalno-treściowe dokumentów ${ }^{4}$.

Nie tylko opracowanie zasad gromadzenia wydaje się skomplikowane, ale także ich stosowanie w praktyce. Rzeczywistość często te normy koryguje i zdarza się, że każdy nowy typ dokumentu wprowadza pewien zamęt w przyjętym i, wydawałoby się, do końca dopracowanym schemacie. Wraz z upływem czasu pojawiają się więc kolejne problemy. Należy tutaj zaznaczyć, że w przeszłości zasady gromadzenia opracowywano na jakiś, zwykle dłuższy, czas. Obecnie wraz z postępem technologicznym i szybszym procesem wydawniczym, a także - z potrzebami rynku, pewne zjawiska występują częściej niż w przeszłości, wymuszając ciągłe zmiany, również w zakresie cech wydawniczych, i tym samym powodując zmiany w pracy z tym typem dokumentu. Stąd druga metoda tworzenia zasad gromadzenia wydaje się bardziej przydatna, gdyż nie wymaga nowych decyzji w związku z ukazaniem się nowego typu czy formy dokumentu. Metoda ta nie wyklucza jednak sytuacji, w której już po kilku latach trzeba aktualizować przemyślane uprzednio i precyzyjnie sformułowane zasady gromadzenia. Pojawiają się nowe formy druków, które często trudno jednoznacznie nazwać, a niektóre zmieniają format i przeznaczenie, co także powoduje zmiany w pracy biblioteki. Zaznaczenia wymaga także fakt, że w stosunkowo krótkim czasie niektóre instytucje i organizacje zmieniły formy komunikowania się ze społeczeństwem i wraz z rozwojem Internetu zrezygnowały z edycji form papierowych, zamieszczając swoje dokumenty na stronach WWW. W formie papierowej wydają to, co jest konieczne i regulowane przepisami prawnymi. Niektóre typy dokumentów zniknęły więc zupełnie z obiegu, a współczesne czasy przyniosły nowe, niewystępujące dotychczas formy druków.

Pamiętne lata 80. to produkcja ogromnej liczby różnorodnych druków o charakterze politycznym; były one przeważnie nielegalne i typowe

${ }^{4}$ Zob. szerzej na ten temat E. Słomianowska-Kamińska, Dokumenty życia społecznego w Bibliotece Uniwersyteckiej w Warszawie - zarys problematyki, „Rocznik Biblioteki Narodowej" 2004, t. 36, s. 193-200, oraz A. Firlej-Buzon, Dokumenty życia społecznego w teorii i praktyce bibliotekarskiej w Polsce, Warszawa 2002. 
dla literatury podziemnej. Lata 90. to okres przemian i kształtowania się nowego typu państwa i tym samym nadal duża liczba druków politycznych, dotyczących różnych aspektów życia społecznego, będących wynikiem dyskusji i ścierania się odmiennych koncepcji politycznych, wydawanych przez różne partie i ugrupowania polityczne - to przede wszystkim druki wyborcze, skierowane do różnych gremiów społecznych. Oprócz tych o tematyce politycznej, pojawia się jednak nowy rodzaj druków reklamujących wszelkie inne formy aktywności społecznej. Zmienia się ich szata graficzna, format, stają się nieodłącznym elementem życia społecznego. Pierwsze lata XXI w. przynoszą nowe zjawiska, znikają niektóre rodzaje dokumentów, pojawiają się nowe formy marketingowe - wielkie billboardy, banery, reklamy przydrożne. Wydaje się, że słowo drukowane „przegrywa” z reklamą wizualną, co jednak nie do końca jest prawdą. Większość partii politycznych umieszcza swoje dokumenty programowe oraz druki zawierające stanowisko partii wobec podstawowych problemów współczesności na swoich stronach WWW. Druki wyborcze także nie są produkowane w tak masowej skali jak kilka lat wcześniej. Najczęściej wydawane druki ulotne, afisze i plakaty pojawiają się w związku z protestami społeczno-politycznymi i różnorodnymi akcjami organizacji pozarządowych. Wydzielone kilka lat temu w magazynie GDŻS BUW miejsce przeznaczone na druki o charakterze politycznym, urzędowym, a także na dokumenty programowe partii świeci pustkami. Wcześniej wszystko drukowano w formie broszur i druków ulotnych czy afiszy.

Innym zjawiskiem jest fakt, że niektóre pojedyncze dokumenty mające charakter druków ulotnych z czasem przybierają formę wydawnictw ciągłych. Wydawnictwami ciągłymi zajmuje się zwykle inny dział, stosuje się wobec nich inny rodzaj opracowania i wraz z ich pojawieniem się znowu trzeba uruchomić procedury mające na celu uwzględnienie nowego charakteru druku i albo przemieścić je do innego działu, albo zastosować odmienne rozwiązania. Dawny podział na: afisze, broszury, druki ulotne, fotografie, jednodniówki, kalendarze, pocztówki czasami traci sens, gdyż niektóre współczesne wydawnictwa mają cechy kilku z powyżej wymienionych form. Do nich można zaliczyć małe plakaciki będące reklamowymi drukami ulotnymi różnych filmów czy pocztówki reklamowe teatrów dramatycznych poświęcone granym w teatrze sztukom, czasami z repertuarem teatru. Stosowanie różnorodnych form jest wynikiem intensywnie działającej reklamy i jednym ze sposobów zabiegania o widza i jest z natury zjawiskiem pozytywnym, ale w sytuacji stosowania przez biblio- 
tekę dosyć sztywnego schematu podziału druków, przyjętego przed kilku laty, zmusza do ciągłych, nie zawsze łatwych, dobrych i możliwych zmian w tym schemacie.

Kolejnym zagadnieniem związanym $\mathrm{z}$ pracą $\mathrm{z}$ dokumentami życia społecznego jest ich przechowywanie. W sztuce bibliotekarskiej jest przyjęte, że zawsze do druku w magazynie prowadzi sygnatura. W sytuacji niemożności nadania sygnatur, gdy większość dżs-ów w bibliotekach akademickich nie jest na bieżąco opracowywana, a jedynie logicznie rozmieszczana w magazynie według określonego schematu, odpowiednia lokalizacja decyduje o szybkim ich udostępnianiu. W przypadku dżs-ów rozmieszczenie jest niekiedy ważniejsze od ich opracowania. Zmiany w schemacie warunkują kolejne zmiany w rozmieszczeniu i często wymagają wszelkiego rodzaju przemieszczeń $w$ ramach pewnych grup druków. Przyjęty w pewnym okresie schemat nie zawsze sprawdza się przez kilka następnych lat, co uwidacznia tempo zmian w publikowaniu aktualnych dokumentów. Ostatnio wydawane druki w związku z prośbą o przeznaczenie przez podatnika $1 \%$ podatku na szczytne cele stawiają bibliotekarza przed koniecznością podjęcia decyzji, gdzie ten druk umieścić: czy w teczce z dokumentami instytucji sprawczej, czy w teczce dotyczącej podatków. Jeżeli zostanie on w teczce instytucji sprawczej, będzie uzupełniał wiedzę o danej instytucji, ale w przypadku pisania przez użytkownika pracy np. o różnych instytucjach zabiegających o ten $1 \%$ podatku nigdy nie znajdzie się kompletu druków tej tematyce poświęconych. Do tego mogą dojść różne formaty druków, jeden może być drukiem złożonym w harmonijkę, a inny może mieć format A3.

W ostatnich latach nastąpił autentyczny zalew różnego rodzaju drukami o różnorodnym przeznaczeniu. Powstaje w związku z tym pytanie, kto powinien je gromadzić. Z punktu widzenia biblioteki akademickiej wszystkie one potencjalnie mogą stać się przedmiotem badań naukowych, ale czy biblioteka tego typu jest w stanie je gromadzić, opracować, przechowywać i udostępniać? Biblioteki akademickie mają m.in. za jedno z głównych zadań przygotowanie warsztatu pracy dla studentów i pracowników naukowych swojej uczelni. Czy Biblioteka Narodowa, do której zadań należy gromadzenie całego piśmiennictwa polskiego, także jest w stanie zgromadzić wszystko w tym zakresie? Czy biblioteki publiczne mogą zapewnić, że zgromadzą wszystko z danego terenu? Wydaje się to dzisiaj dosyć trudnym do jednoznacznego rozstrzygnięcia problemem. Biblioteka Uniwersytecka w Warszawie będąca biblioteką główną Uni- 
wersytetu Warszawskiego stara się gromadzić dokumenty życia społecznego dla całej społeczności akademickiej, biblioteki wydziałowe bowiem tego typu druków nie gromadzą. Na Uniwersytecie jest około 250 kierunków i różnego typu specjalizacji i z założenia dla tych kierunków Biblioteka powinna gromadzić to, co może być przydatne do badań naukowych. $\mathrm{Z}$ drugiej strony, czy w swojej nowej siedzibie, dysponując wprawdzie odpowiednimi powierzchniami magazynowymi, ale przy dwuosobowej obsadzie personalnej, jest ona w stanie realizować swoje zadania $w$ tym zakresie? Jak więc pogodzić te dwa problemy? Jak dokonać prawidłowej selekcji napływających materiałów? Zawsze przy tym powstaje pytanie, co będzie przydatne w przyszłości, a co nie. Nigdy też nie można przewidzieć, w którym momencie jakaś określona grupa druków, często całkiem zapomniana, stanie się przedmiotem badań i szczególnych zainteresowań. Praktyka pracy z tymi materiałami jest tylko potwierdzeniem powyższych wątpliwości. Ponadto należy przypomnieć, że rocznie do GDŻS BUW wpływa ponad 10000 druków i można z całą pewnością stwierdzić, że tylko tyle ten zespół pracowniczy może przygotować do ewentualnego udostępnienia, reszta pozostaje do rozpatrzenia na następny rok. Wśród bibliotekarzy trwają dyskusje, jak ten problem rozwiązać i w jakim kierunku iść. Niektórzy proponują specjalizację poszczególnych bibliotek w tym zakresie, ale czy w warunkach wielkiej, uniwersalnej biblioteki można mówić o specjalizacji? W przypadku BUW jest to propozycja raczej kontrowersyjna, ponieważ od momentu jej powstania gromadzono w niej druki, które dzisiaj nazywamy dokumentami życia społecznego, stanowią one część zbiorów głównych, czasami są niezwykle rzadkie, mają charakter unikatowy i stanowią o jej wartości. Wydaje się, że w przeszłości nie przywiązywano do nich zbyt dużej wagi, ale skrupulatnie je gromadzono i dopiero dzisiaj są swoistymi „rarytasami”. Okazało się to po opracowaniu druków z lat 1801-1939 i umieszczeniu ich w katalogu on-line BUW.

W niniejszym opracowaniu nie znalazło się stanowisko wobec jeszcze innego zjawiska, mianowicie wobec wszystkich dodatków do różnych wydawnictw, które to dodatki nie stanowią integralnej części danego wydawnictwa, a są albo zbiorem reklam, albo zbiorem zeszytów wydanych w celach edukacyjnych. Problem wymaga wielu przemyśleń i podjęcia odpowiednich decyzji. W niniejszym materiale należy go jednak zasygnalizować, gdyż ten typ wydawnictw nie należy do rzadkości. Współcześni wydawcy wyraźnie upodobali sobie tę formę. 
Otwartym problemem pozostaje kompletność grup zbiorów. W aktualnej sytuacji trudno stwierdzić, jaką część dżs-ów udaje się bibliotekom zgromadzić. Zapewnienie kompletności jest raczej niemożliwe. Rozwiązaniem pozytywnym wydaje się posiadanie pewnej reprezentacji wydawnictw określonego typu. Gromadzenie różnych form druków, nawet w wyborze, często daje możliwość zapoznania się z nimi i na tej podstawie wypracowania sobie jakiegoś sądu. Nierzadko bowiem można się spotkać ze stwierdzeniem użytkownika (nawet z tytułem naukowym), że ogląda pewien typ druku po raz pierwszy, a jego dotychczasowa wiedza o danym wydawnictwie została wyniesiona z literatury przedmiotu. Najczęściej zdarza się, że użytkownik nie zdaje sobie sprawy z istnienia pewnych form wydawniczych, przechowywanych w bibliotece, pochodzących np. z XIX w. czy z przełomu wieków. Warto więc gromadzić i tworzyć unikatowe, małe kolekcje np. XIX-wiecznych laurek, karnetów balowych czy karnetów z powinszowaniami, telegramów patriotycznych, nalepek okiennych czy znaczków kwestarskich - form druków już o charakterze historycznym ${ }^{5}$.

Nieodłącznym elementem gromadzenia jest opracowanie bądź takie wstępne przygotowanie druków, by w każdej chwili można było do nich dotrzeć i je udostępnić. Biblioteki nie tylko nie nadążają z gromadzeniem tak dużej liczby różnorodnych druków, ale także, co jest oczywiste, z ich opracowaniem. Wymogi katalogowania nie dają szans na szybkie wprowadzenie danych do katalogów komputerowych. Żadna z wielkich bibliotek w Polsce nie jest w stanie opracować wszystkich znajdujących się w niej dżs-ów. Biblioteki najczęściej wybierają do opracowania jakieś cenne kolekcje lub grupy zbiorów uznawane przez bibliotekarzy i użytkowników za ważne w danym momencie, pozostałe druki są akcesjonowane, opieczętowane i składane do magazynu zgodnie z obowiązującymi w danej bibliotece zasadami.

Jak już zostało powyżej wspomniane, pochodną problemów związanych z gromadzeniem i opracowaniem dokumentów życia społecznego są problemy z przechowywaniem takiej liczby druków. Zawsze wymagały one specjalnego traktowania, gdyż są niezwykle zróżnicowane pod

${ }^{5}$ Unikatowy charakter mogą mieć także kolekcje druków współczesnych. Zob. szerzej na ten temat E. Słomianowska-Kamińska, Problematyka pogranicza $w$ dokumentach życia społecznego (na przykładzie zbiorów Gabinetu Dokumentów Życia Społecznego Biblioteki Uniwersyteckiej w Warszawie), „Studia Bibliologiczne”, t. 17: Centrum i pogranicze $w$ polskiej kulturze wydawniczej i czytelniczej. (Wybrane aspekty badań bibliologicznych i szkice historyczne), pod red. E. Gondek i I. Sochy, Katowice 2008, s. 42-56. 
względem formy i treści. Z powodu nienadążania bibliotek z ich opracowaniem ważnym elementem pracy z tymi drukami, jak już zasygnalizowano, jest ich rozmieszczenie w magazynie i szybkie dotarcie do nich. W BUW plakaty i afisze są przechowywane w komodach bądź na szerokich półkach. Każda z półek jest oznakowana zgodnie ze schematem ich rozmieszczenia. Schemat przewiduje 22 szerokie kategorie, a w ramach kategorii dokonano podziału bądź na grupy tematyczne, bądź na instytucje sprawcze - w zależności od materiału i potrzeb (wynikających zwykle z poszukiwań użytkowników). Rocznie do BUW wpływa około 1000 plakatów i afiszy, relatywnie nie jest to zbyt duża grupa wydawnictw. Najwięcej wpływa druków ulotnych i niewielkich folderów. Są one przechowywane w teczkach lub pudłach. W szybkim tempie rośnie objętość teczek i pudeł, które z kolei są ustawiane na półkach. Na koniec 2009 r. zbiory GDŻS BUW liczyły ponad 214000 jednostek. W związku z powyższym zawsze powstaje pytanie, na ile jeszcze lat wystarczająca będzie powierzchnia magazynowa. Obawa przed tzw. zapchaniem magazynu często jest powodem do ograniczania się w gromadzeniu druków. Powstaje więc zamknięte koło. Wiadomo jednak, że zarówno brak miejsca, jak i swoista nieprzewidywalność w ewentualnym wykorzystaniu przez użytkownika nie powinny być kryterium pracy bibliotekarskiej. Wykorzystanie bądź niewykorzystanie zbiorów jest problemem, który nie powinien zaprzątać głowy bibliotekarzom. Tak samo można podejść do problemu miejsca w magazynie. Tylko że w praktyce każdy bibliotekarz w pewnym momencie musi zmierzyć się z tym problemem.

\section{Ephemera in academic libraries - some dilemmas Abstract}

Ephemera as a separate group of library collections are a new phenomenon in Polish academic and research libraries. Ephemera belong to special collections and play a significant role in various areas of scholarly research. Libraries have not agreed upon a detailed definition of ephemera so far. Ephemera most often tend to include various printed items concerning multiple domains of social life and reflecting internal activities of various organizations, associations and institutions. Published in the form of broadsides, leaflets, monographs and serials for temporary informational, propaganda, advertising and standardizing pur- 
poses, addressed to clearly defined audience, boasting a varied form and layout, they usually are distributed via channels other than regular bookshops. Some libraries use their own specific criteria for identifying and collecting ephemera. Recently the production of ephemera has witnessed an incredible boom as they became an indispensable part of everyday life. Libraries know this issue in detail due to their growing problems with acquiring, cataloging and storing ephemera. Any decision made as regards ephemera in libraries is bound to be very controversial. 